\title{
О ТМЕЗИЧКОЈ ПЕРМУТАЦИЈИ ЕНКЛИТИКЕ „ЛИ” У РАЗГОВОРНОМ ЈЕЗИКУ ${ }^{* *}$
}

\begin{abstract}
У раду се, на примјерима из новинарског подстила публицистичког стила српског језика, са структурног, семантичког и нормативног аспекта анализира један специфичан тип разговорне (колоквијалне) упитне конструкције: Je л’ $c m e$ здраво? Рад нуди одговоре на питања: како и зашто је настала ова тмезичка упитна конструкција.

Кључне ријечи: разговорни језик, тмеза, упитна реченица, ненормативност, ријечца „ли” сложена ријечца „да ли”, енклитички спој ,је ли”.
\end{abstract}

У раду анализирамо случајеве у којима се једна лексема разбија енклитичком ријечцом „ли” на своје саставне дијелове, тако да у резултату тог тмезичког разлагања од дволексичке структуре (пунозначне лексеме и ријечце „ли”) добијемо тролексичку структуру. Специфичност тмезе с ријечцом ли у томе је што та ријечца, никад у свом пуном него увијек у апокопираном облику л', ,разбија” тоничку ријеч с којим чини акценатску цјелину, али та тоничка ријеч није сложеница. Изневјеравају се двије битне карактеристике праве граматичке тмезе ${ }^{1}$ : не разлаже се на компоненте сложена него проста ријеч, а у том разлагању просте ријечи никад не учествује пуни облик, него

*mkovacevic31@gmail.com

** Рад је настао у оквиру пројекта 178014: Динамика структура савременог српског језика, који финансира Министарство просвете, науке и технолошког развоја Републике Србије.

${ }^{1}$ Тмеза може бити граматичка и стилистичка (Ковачевић 2015a: 229-239). Као граматички термин, како то наводе рјечници (нпр. Симеон 1969: 616; Клајн/Шипка 2008:1252), тмеза значи растављање једне по правилу сложене ријечи тако што се између њених дијелова умеће нека друга ријеч. Тмезичку структуру у српском језику увијек имају одричне замјенице употријебљене у неком зависном падежу с предлогом, тј. у некој предлошко-падежној конструкцији, као нпр.: нико $\rightarrow$ ни од кога, ни за ким, ни о коме, ни због кога; ништа $\rightarrow$ ни од чега; ни за чим, ни на чтоо, ни због чега, и сл. 
искључиво скраћени, апокопирани облик енклитичке ријечце. За потврду ћемо засад навести само два парадигматична примјера²:

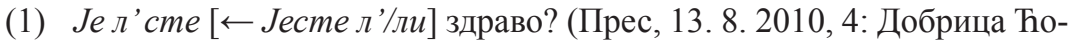

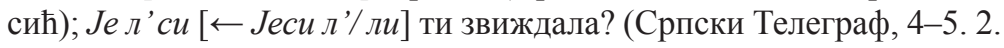
2017, 21).

Овакава тмезичка пермутација остварује се само у једном обличком типу упитних реченица: у упитним реченицама које се творе упитном ријечцом ли употријебљеном иза тоничких облика глагола бити (јесам) у предикату израженом перфектом (или плусквамперфектом) као сложеним глаголским обликом или презентом с именским или прилошким предикативом. Дата тмезичка конструкција одлика је разговорног, а не књижевног или стандардног језика.

Како је и зашто у разговорном језику настала ова тмезичка упитна конструкција - основна су питања на које одговоре треба да понуди овај рад. А пут до одговора води преко суодносне анализе упитних реченица творених упитном енклитичком ријечцом ли и оних творених сложеном упитном ријечцом дали.

Зато ћемо најприје указати на међуоднос ових двају обличких типова упитних реченица у српском језику. Сложена упитна ријечца да ли има слободну дистрибуцију: њом се творе упитне реченице уз било који - прости или сложени - морфолошки тип предиката, што потврђују и сљедећи примјери:

(2) Да ли је жив Милан? (Политика, 24. 3. 2019, 24); Да ли је то и даље тако? (Блиц, 17. 3. 2019, 13); Да ли о томе неко размишља у Вашингтону? (Политика, 9. 3. 2019, 18); Да ли сте се надали повратку у репрезентацију? (Политика, 13. 3. 2019, 19); Да ли ћете одсвирати и неку нову песму? (Вечерње новости, 18. 3. 2019, 17); Да ли бисте ми се придружили у прослави Празника рада? (Данас, 8. 5. 2019, 18) и сл.

Сложена ријечца да ли, како се и из наведених примјера види, долази на почетку упитне реченице (или, као у посљедњем примјеру, зависноупитне клаузе) без обзира да ли је предикат реченице неглаголски (копулативни) или је у питању прости или сложени глаголски предикат, с тим да није битно да ли је прости глаголски предикат изражен морфолошки простим или сложеним глаголским обликом. Једноставно речено, употребом сложене упит-

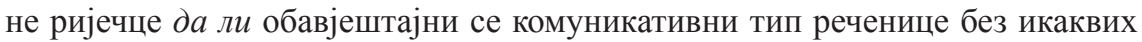
структурних и морфолошких измјена преводи у интерогативни.

Употреба упитне енклитичке ријечце ли дистрибуцијски је еквивалентна употреби сложене ријечце да ли, што значи да се и помоћу те ријечце могу творити упитне форме реченица без обзира какав је њихов морфолошки или синтаксички тип предиката. Ријечца ли и сложена ријечца да ли битно се, међутим, разликују у погледу мјеста које заузимају у структури упитне

\footnotetext{
${ }^{2}$ Сви примјери који се у раду наводе ексцерпирани су из новина које наводимо у Изворима на крају рада. Сва истицања у примјерима, углавном курзивна, накнадна су, тј. наша - МК.
} 
реченице. За разлику од сложене ријечце $ә а л и$, енклитичка ријечца ли не може доћи на почетку упитне реченице, него увијек долази на другом мјесту, иза акцентоване глаголске лексеме. Зависно од тога да ли је у саставу предиката употријебљен или није несвршени глагол бити, односно јесам, све упитне реченице творене ријечцом ли могу се подијелити у два типа: a) упитне реченице творене ријечцом ли употријебљеном након презентског облика пунозначног, модалног или фазног глагола на почетку реченице, б) упитне реченице творене ријечцом ли употријебљеном након презентског или аористног облика глагола бити на почетку реченице када је у питању неглаголски (копулативни) предикат или сложени глаголски облик који у свом саставу има презентски или аористни облик глагола бити. Ево за потврду по неколико примјера и за један и за други тип упитних реченица творених ријечцом ли: ${ }^{3}$

(3) Може ли опстати српско село? (Данас, 6. 3. 2019, 8); Видите ли ви шта о мени пишу? (Данас, 6. 3. 2019, 28); Хоће ли неко ово да заустави? (Политика, 12. 3. 2019, 9); Одобравате ли готовинске наменске кредите? (Вечерње новости, 13. 3. 2019, 2); Недостаје ли вам Србија? (Блиц, 27-29. 4. 2019, 34); Има ли Партизан рецепт за Звезду? (Политика, 24. 4. 2019, 18: наслов) итд.

(4) Јесте ли ви верник? (Политика, 1. 7. 2019, 13); Јесте ли ту у августу? (Политика, 17. 3. 2019, 23); Јесте ли спремни за турнир? (Вечерње новости, 27. 5. 2019, 32); Јесу ли бол и љубав богатство? (Блиц, 30.4 - 2. 5. 2019, 33); Јеси ли то пошао у шетњу? (Данас, 23-24. 3. 2019, додатак Недеља, II); А јеси ли и докторирао? (Данас, 14. 5. 2019, 10); - Јесам ли видела добро? (Вечерње новости, 20. 5. 2019, 16); Јесте ли чули за термин „џванкање”? (Блиц, 19. 5. 2019, 20) итд.

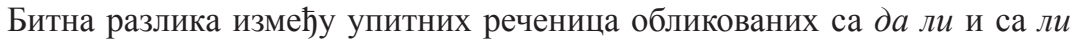
јавља се само при творби реченица са глаголом бити (јесам) у саставу предиката, какви су примјери (4). Са да ли енклитички облик копулативног или помоћног глагола бити (сам, си, је, смо, сте, су), реализован непосредно након да ли, обавезно је у саставу предиката, док са ли, осим у трећем лицу једнине, глагол бити (јесам) долази само у акцентованом, ортотонијском облику (јесам, јеси, јесмо, јесте, јесу), и то испред ријечце ли.

(5) Да ли су натпросечно вредни? : Јесу ли натпросечно вредни?; Јеси ли докторирао? : Да ли си докторирао? итд.

Само се у једном случају упитних реченица са да ли и ли с предикатима који у свом саставу имају копулативни или помоћни глагол бити (јесам) предикати облички подударају, и то када је у саставу предиката употријебљен облик трећег лица једнине презента. У саставу таквог предиката никад се,

\footnotetext{
${ }^{3} \mathrm{C}$ тим да нећемо наводити примјере с аористним обликом помоћног глагола бити на почетку реченице и упитном речцом ли, јер тај тип упитне реченице није у вези са тематиком нашег рада.
} 
без обзира да ли се упитна реченица твори са да ли или ли, не употребљава акцентовани облик трећега лица jecm(e), него искључиво енклитички облик je, само што у реченицама са да ли енклитика је долази послије упитног маркера да ли (в. примјере под 2), док у реченицама са ли та енклитика долази на почетку реченице, тј. испред ли, чему су потврда сљедећи примјери:

(4а) Је ли то пораз? (Вечерње новости, 26. 4. 2019, 23); Је ли могуће да не постоји начин да се прогони зауставе? (Политика, 7. 3. 2019, 20); Је ли тешко бити редитељка у Бејруту? (Политика, 16. 3. 2019, КУН, 2); Је ли истина да сте на почетку каријере каснили на посао? (Блиц, 10. 3. 2019, 11); Је ли је пољубио? (Политика, 23. 3. 2019, 18); Је ли причао послије гдје је био и шта је радио? (Политика, 24. 3. 2019, 26) итд.

У питању је „изузетан случај употребе енклитичког облика 3. л. једнине (je) на почетку упитне реченице. Он је, прво, изузетан по томе што је то једини случај у српскохрватском књижевном језику да се енклитика употребљава на почетку реченице. А пада у очи и по томе што се облици осталих лица и помоћног глагола јесам употребљавају на почетку упитних реченица само у акценатским, тј. пуним облицима" (Стевановић 1979: 14). Међутим, у вези са енклитиком ли, у споју је ли, презентски облик је губи статус енклитике. У споју је ли енклитике се „наслањају” једна на другу ${ }^{4}$ а затим заједно на трећу ријеч која има акценат. Тако се питање Је ли јӓсно?, иако се пише као три ријечи, изговара као једна ријеч, као цјелина с једним акцентом: Јели јӓсно? И то је, вјероватно, јединствен случај у српском језику да спој двију атоничких, енклитичких јединица творе својесврсну „енклитичку” проклитику.

Употреба упитне ријечце ли у споју је ли још се по једној особини битно разликује од напријед анализираних комбинација ријечце ли са пунозначним, модалним, фазним глаголима или пак са ортотонијским облицима глагола бити (јесам), а то је њена апокопирана форма - је л'. Апокопирање ли иза пунозначног глагола готово да је оказионално, ни иза акцентованих облика глагола бити није често (јесмо л', јеси л', јесте л', јесу л'), али је зато врло обично и распрострањено у споју је ли, чему су потврда и сљедећи корпусни примјери:

(4б) Је л’ то неслана шала? (Вечерње новости, 18. 4. 2018, 2); Је л’ било пропуста у вршењу те акције? (Блиц, 20. 3. 2018, 5); Jе л’ ту Мики Манојловић? (Данас, 22. 8. 2019, 10); Је л’ љубоморна? (Блиц, 19. 3. 2019, Поп\&Култура, 4); Је л’ било тог мејла или није? (Блиц, 2. 7. 2019, 13); Па је л’то у реду? (Политика, 1. 7. 2019, 13); Тето, је л' ова кућа наша? (Блиц, 14. 6. 2019, 2) итд.

\footnotetext{
${ }^{4}$ И како, погрешно, наводи љ. Поповић, ,,а слажу се у овом случају са ортотоничким облицима помоћних глагола” (Поповић 1997: 285). Погрешно, зато што ,је ли” акценатску цјелину чине тек с наредном акцентованом ријечи. Скуп „да ли” има статус сличан или чак подударан статусу неакцентованих проклитика.
} 
Апокопирана форма је л’ подобнија је за „улексемљење” од неапокопиране је ли. У је ли се јасно извајају двије компоненте, па је њихово срастање готово искључено, док се форма је л' као тоничка цјелина осјећа и као монолексичка цјелина. И то не само у говору него и у писању5: пише се као једна лексема јел, посебно још кад изостане знак за апостроф. Истина сусрећу се примјери и са улексемљеним јел са апострофом јел'и без ње - јел:

(4в) Јел' јасно? (Данас, 23. 1. 2019, 16); Јел то једини случај у Србији? (Вечерње новости, 17. 3. 2019, 27); А она, јел'повређена? (Вечерње новости, 17. 3. 2019, 27); Ало, јел' то полиција? (Данас, 22. 5. 2019, 10); Јел' повређена? (Данас, 5. 6. 2019, 8); Кардељ га је [Перу Зупца], кад је овај завршио, питао - а јел’ било после нешто? (Данас, 4-5. 5. 2019, додатак Недеља, III: Зоран Пановић); и сл.

У свим наведеним примјерима сем посљедњег предикат реченице је неглаголски (именски или прилошки) с тим да је копулативни дио предиката садржан у улексемљеном упитном маркеру јел или јел'. Исти је случај и са посљедњим примјером у коме је употријебљен перфекат у предикату ${ }^{6}$ (jел' било).

Један од разлога стварања улексемљеног јел без апострофа вјероватно је и неразликовање употребе зависног узрочног везника јер и енклитичког упитног споја јел у разговорном језику, које је, то неразликовање, „све распрострањеније чак и међу школованима” (Стијовић 2012: 139), а потврђују га и сљедећи забиљежени примјери из новинарског језика:

(5) Питам: јер [ $\rightarrow$ jел] ово друг-ица скраћеница друга конференција? (Вечерње новости, 11. 10. 2008, 25: Миња Богавац); Јер [ $\rightarrow$ Јел] тачно да ви феминисткиње не депилирате ноге? (Вечерње новости, 11. 10. 2008, 25: Миња Богавац); Ђурић је „морао” да оде на Косово, jел $[\rightarrow$ jep] да није отишао планета би престала да се окреће (Данас, 29. 3. 2018, 11); Је л [ $\rightarrow$ jep] да је то рекао, наводи историчарка Стојановић, то би значило да је против сецесионистичког Републике Српске модела (Данас, 23. 10. 2019, 8: Перо Симић); итд.

\footnotetext{
${ }^{5}$ Што је, истина нејасно, и правописно прописано. Наиме, у правописном рјечнику уз одредницу је ли каже се „питање и узречица; разг.: јел', јелте, јелда” (Правопис 2010: 336), док се у тексту правописа у т. 133. каже „Одвојено се пише и узречица (у разговорном стилу) је ли: у множини се употребљава редуковани облик јелте." (Правопис 2010: 94). У нормативним савјетницима дају се различити, покаткад и супротни, предлози правописних решења за различите форме споја је ли (в. нпр.: Клајн 2008: 110, 132; Фекете 2008: 7-72).

${ }^{6}$ Кад је у перфекту употријебљен повратни глагол, онда у трећем лицу једнине у контактни положај долазе енклитике се је, па долази до упрошћавања сажимањем „енклитика се је, које се у изговору обично сведе на $c \hat{e}(c e j e>c e e>c \hat{e})$, те смо тако од окренуо се је добили окренуо се, од дигао се је - дигао се, од прочуло се је - прочуло се итд.” (Стевановић 1981:100). У тим упитним реченицама са повратним глаголом у трећем лицу једнине перфекта ствара се привид да се могу

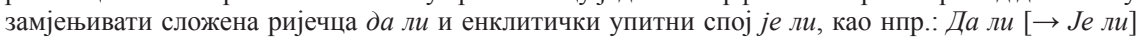
се Цица и вама јавила? (Политика, 23. 3. 2019, 18); Да ли [ $\rightarrow$ Је ли] се иједном догодило да сам негирао интегритет БиХ? (Вечерње новости, 30. 4-2.5. 2019, 2). Међутим, само у реченицама са да ли перфекатски облик је сажет (без енклитика је), док у реченицама са је ли сажимања нема, нити је могуће, јер се јављају обје енклитике и је (у је ли) и се.
} 
Употреба узрочног везника јер умјесто упитног споја јел, и обрнуто, „представља грубу грешку”, односно „грубо нарушавање српске граматичке норме" (Пипер/Клајн 2013: 421, 514). Они који употребљавају јел умјесто јер то јел и не доводе у везу са је ли, него га прихватају као једну лексему еквивалентну лексеми јер, што је индикатор да се у оваквим случајевима јел мора писати без апострофа (зато што ни јер нема апострофа), а што даље значи да је јел - које је настало од краћег облика помоћног глагола јест(е) и скраћене упитне ријечце ли - сада добило статус монолексичке упитне ријечце. ${ }^{7}$

У нормативној се литератури наводи да су „реченице с конструкцијом јел' одлика разговорног стила и да се у другим стиловима ни оне не препоручују" (Стијовић 2012: 140). Међутим, иако за питање Јел' знаш ко нам долази? наводи да је „одлика колоквијалног изражавања”, П. Пипер ће непосредно иза тога написати: „Ако је предикат у презентском облику пунозначног глагола, осим речци ли и да ли може бити употребљена речца јел', која ту има статус посебне упитне речце, а не дела сложеног глаголског облика, нпр. Јел' читаш?" (Пипер 2005:675). Питање је, међутим, у чему је разлика између питања Јел' знаш ко нам долази?, које је проглашено „колоквијалним”, и питања Јел'читаш?, које ваљда треба схватити као нормативно неспорно јер је дато за поткрепу правила творбе упитних реченица с презентским предикатом пунозначних глагола?!

Истина је, међутим, да су у разговорном језику, који у овоме раду репрезентују примјери из публицистичког стила, врло честе упитне реченице творене са а) је л' или б) јел/јел' уз презентски предикат изражен пунозначним глаголом, што потврђују и сљедећи забиљежени примјери:

(6) Је л' људи воле анегдотице? (Курир, 2. 3. 2012, 26); Је л’ грађански рат почиње сам од себе или има неко свечано отварање? (Вечерње новости, 11. 4. 2019, 2); Jе л' видите да у фудбалу увек има горе? (Вечерње новости, 10. 6. 2019, 32); Сместа напоље, је л' ме чујеш? (Политика, 26. 5. 2019, 23: Момо Капор); Је л'знају студенти да препознају то што од њих тражите? (Данас, 3. 5. 2019, 7); Је л'планирате да отворите неку компанију у општини Ражањ? (Блиц, 3. 3. 2019, 3); Је л' правите венце? (Блиц, 11. 8. 2019, 13); Је л'има студената који би блокирали овај факултет? (Вечерње новости, 13. 5. 2019, 3); Је л' ти хоћеш да мене Слоба убије? (Блиц, 28. 1. 2018, 5); Јел' ме разумеш, куме? (Вечерње новости, 11. 9. 2019, 18);

Јел ви то хоћете да постанемо комби странка?! (Вечерње новости, 12. 3. 2019, 2); А јел' има он бејзбол палицу? (Вечерње новости, 8. 4. 2019, 2); Каже: јел ти се не чини као да сам ту? (Данас, 10-11. 2. 2018, Недеља, IV); Јел ти слушаш да је фасцикла потпуно празна! (Данас, 27. 6. 2018, 16); ...а он јој одговори: „Јел’ ти то сматраш

\footnotetext{
${ }^{7}$ Анализирајући говор београдских глумаца из телевизијске серије Самаи у браку, Душка Кликовац закључује да се „у серији општа питања најчешће постављају на начин који није својствен негованом говору - помоћу речце јел" (Кликовац 2018:112). Ту речцу Д. Кликовац и пише као једну ријеч и без апострофа (јел). Уз то, Д. Кликовац у датој серији биљежи и примјере у којима се јавља ,,јер уместо јел”: Јер $[\rightarrow$ jел] ме волиш?; Јер $[\rightarrow$ jeл] је рекла? (Кликовац 2018: 112).
} 
нормалним?” (Данас, 10-11. 3. 2018, додатак Недеља, III); Тата, јел' могу да истражим има ли у нашој фирми непотизма? (Вечерње новости, 17. 2. 2019, 27); Па јел треба да трпимо? (Данас, 19-20. 10. 2019, 7); итд.

Разлике између је л’ и јел'/јел нема у говорном језику, јер се оба лексичка споја изговарају као једна тоничка цјелина. Разлика је само у писаном језику јер је један спој (је л') написан као дволексички, а други (јел/јел ') као монолексички. У свим наведеним примјерима с презентским предикатом пунозначног глагола и монолексички и дволексички написан спој има вриједност упитне ријечце, и синониман је сложеној упитној ријечци да ли /да л', која га, сљедствено, у свим наведеним примјерима може замијенити. Као што ни елементи сложене ријечце $\partial а$ ли не улазе у структуру предиката, тако ни дио структуре предиката није монолексичка ријечца јел/јел', али то такође није ниједан од елемената сложене ријечце је л' (jер је предикат изражен презентом пунозначног глагола прости морфолошки глаголски облик, а енклитика је може бити само дио или сложеног неглаголског предиката, или морфолошки сложеног глаголског облика).

Да је у овом случају у питању само правописно диференцирана проста (jeл/jел') или сложена (је л') ријечца, показује не само могућност њене замјене сложеном ријечцом да ли, него и могућност употребе испред глаголских облика у предикатима чија структурна компонента није нити може бити енклитика је која је саставни дио просте или сложене ријечце, чему су показатељ, не само напријед наведени примјери, него и примјери што слиједе:

(6а) Хајде лепо склони те новине и признај: је л' да би ти било много лепше да си сам, без нас двоје, а? (Политика, 26. 5. 2019, 23: Момо Капор); Да се ваша ћерка смувала са човеком од 30+, је л' би и тада било „љубав не зна за године”? (Курир, 29. 6. 2019, 18); „Јел’ оно беше на паради исто имају ракете?" - унапред нарогушен се наглас запитао Живорад. (Вечерње новости, 6. 5. 2018, 2) и сл.

У сва три наведена примјера, од којих су у прва два предикати изражени потенцијалом, а у трећем комбинацијом презента и имперфекта (беше uмajy) ${ }^{8}$, могућа је замјена јел/jе л' са да ли, с тим да у првом примјеру та замјена не би била потпуно значењски еквивалентна, јер би употреба да ли укинула компоненту значења сугестивности питања, коју носи везник $\partial a$ нужно испустив при употреби ријечце да ли због већ присутне компоненте да у њеном саставу.

Као што је монолексички или дволексички апокопирани спој јел’/je л’ у разговорном језику замјењив сложеном ријечцом да ли, исто тако се (да ли само у разговорном језику?) сусрећу и случајеви употребе неапокопираног споја је ли у вриједности сложене ријечце да ли, као нпр.:

(6б) Је ли долазиш? (Правопис 2010: 94); Је ли то значи да нас двоје сада сједимо и разговарамо у мраку? (Данас, 9-10. 3. 2019, додатак Недеља, XIII) и сл.

${ }^{8}$ О конструкцијама типа „беше имао” в. у Ковачевић (2008: 149-161). 
Пошто је у наведеним примјерима у предикату презент пунозначног глагола, ,jе” никако не може бити дио предиката, него са ли чини сложену ријечцу је ли синонимну сложеној ријечци да ли. Зато је у литератури и постављано питање о конкурентности је ли и да ли, посебно с обзиром на нормативни аспект њихове употребе. Тако су хрватски нормативисти сматрали да „упитној честичној/везничкој скупини је ли треба у стандардном језику дати предност пред скупином да ли" (Худечек/Вукојевић 2007: 217-218). Детаљнија анализа показала је, међутим, да је „такав савјет неточан, а примјери показују да се у правилу жељело казати да умјесто скупине да ли треба употребљавати честицу ли којој претходи предикат или предикатна копула ако је ријеч о именскоме предикату. Та копула може дакако бити у 3. лицу презента, па онда реченица 'случајно' започиње с је ли, али тада то није честична скупина је ли" (Худечек/Вукојевић 2007: 218-219). Из тога онда нужно произлази да је употреба скупине ,је ли" могућа само за питање у трећем лицу једнине предиката који у свом саставу имају презентске облике глагола бити (јесам). Конкретно речено, нормативним се не могу сматрати случајеви употребе ,jе ли” умјесто „да ли” испред предиката изражених презентом пунозначних глагола, какав је нпр. Је ли долазиш?, који, невјероватно, као нормативан доноси српски Правопис. ${ }^{9}$

У оваквој у разговорном језику врло фреквентној употреби је ли (и њених ортографских варијанти је л'/زел'/јел) у функцији општеупитне ријечце лексема - ,је” губи статус глаголске енклитике, уједињујући се са партикулом ли у сложену партикулу. А то онда нужно доводи до линеарног преструктурисања дијела предиката израженог копулативним или помоћним глаголом бити (јесам). Акцентовани презентски облик глагола бити раставља се на два дијела - на је и енклитички облик: сам, си, смо, сте и су. Између компоненте ,je" и енклитичког презентског облика глагола бити интерполира се апокопирана форма упитне партикуле ли (форма $л^{\prime}$ ), тако да добијамо тмезичку тролексичку структуру: је + л’ + енлитички облик презента глагола бити (у свим лицима сем у трећем лицу једнине):

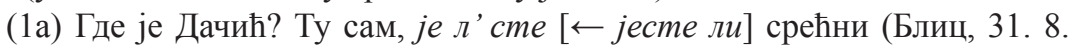

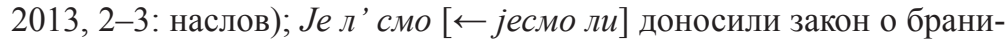
тељима или они? (Курир, 6-7. 1. 2018, 5: Александар Вучић); Је л'

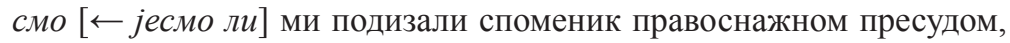
доказаном терористи какав је Миро Баришић? (Курир, 6-7. 1. 2018,

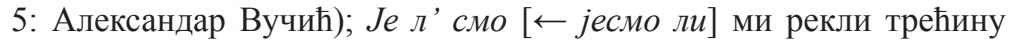
Срба треба покрстити, трећину протерати, трећину убити? (Курир,

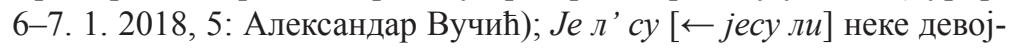
ке намештене? (Курир, 3. 4. 2012, 22); У једном тренутку сам га

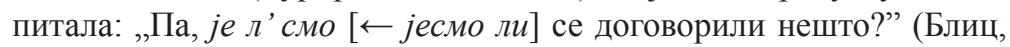
5. 4. 2018, Блиц сцена, 8); Па, је л’ сте [Ł јесте ли] отворили неку ординацију, осим што лепо причате сад? (Курир, 21. 3. 2012, 5: Дра-

\footnotetext{
${ }^{9}$ „Ако је речца ли повезана с карактером реченице или с глаголом, пише се одвојено: Је ли долазии?" [sic!] (Правопис 2010:94).
} 


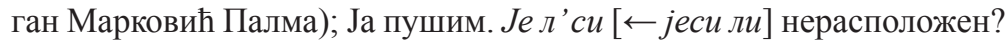
(Вечерње новости, 16. 10. 2011, 26: Светозар Влајковић);-Jе л'сте [ черње новости, 10. 7. 2009, додатак „ТВ новости” од 11-17. 7. 2009,

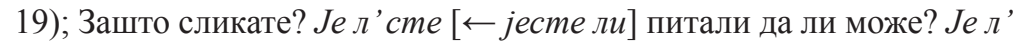

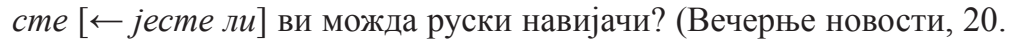
7. 2010, 48: Радомир Антић); ...и питао девојку: „Ана је л’си [ ли] то ти?” (Блиц, 26. 4. 2009, 13) итд.

Само од правописног рјешења да ли ће се апокопирана ријечца писати одвојено или састављено са глаголском енклитиком ,jе” зависи и да ли ће тмезичка структура бити тролексичка или дволексичка. У корпусу су, уз напријед наведене тролексичке, забиљежени и примјери дволексичке тмезичке структуре:

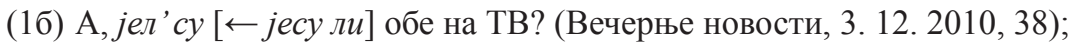

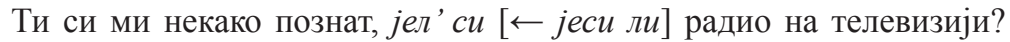
(Политика, 23. 10. 2018, 22); Не знам јел' си [њ јеси ли] глед’о ону сахрану? (Вечерње новости, 6. 5. 2018, 2); Нисам обраћао пажњу на те порнографске снимке док ме колега током „шетње за Оливера

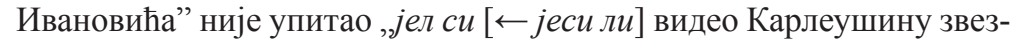
дицу?” (Данас, 21. 1. 2019, 1) итд.

И тролексичка, и дволексичка тмезичка структура упитне реченице обичне су у разговорном језику. Припадају колоквијалном стилу изражавања и не могу се сматрати нормативним. Интересантно је да богата савјетничка нормативна литература овај тип огрешења о језичку норму и не региструје. Ваљда због толико великог броја очигледнијих нормативних огрешења у вези са употребом споја састављеног од енклитичког облика глагола бити и (не)апокопиране ријечце ли.

\section{ИЗВОРИ}

Блиц - Blic, dnevne novine iz Beograda.

Вечерње новости - Вечерње новости, дневне новине из Београда.

Данас-Danas, dnevne novine iz Beograda.

Курир - Kurir, dnevne novine iz Beograda.

Преc - Press, dnevne, ugašene, novine iz Beograda.

Политика - Политика, дневне новине из Београда.

Српски Телеграф - Srpski Telegraf, dnevne novine iz Beograda. 


\section{ЛИТЕРАТУРА}

Клајн 2008: Иван Клајн, Речник језичких недоумииа, девето издање, Нови Сад: Прометеј.

Клајн/Шипка 2008: Иван Клајн, Милан Шипка, Велики речник страних речи и израза, Нови сад: Прометеј.

Кликовац 2018: Душка Кликовац, О савременом српском језику и савременој свести о њему (на материјалу телевизијске серије Самаи у бра$\kappa y)$, у: Језици и културе у времену и простору, VII/2, Тематски зборник, уреднице Снежана Гудурић и Јелена Ајџановић, Нови Сад: Филозофски факултет, 99-118.

Ковачевић 2008: Милош Ковачевић, О деиктичкој употреби имперфекта, Српски језик, XIII/1-2, 149-161.

Ковачевић 2015a: Милош Ковачевић, Тмеза и дијакопа, у: Стилистика и граматика стилских фигура, IV битно допуњено издање, Београд: Јасен, 229-239.

Пипер 2005: Предраг Пипер, Интерогативност, у: Предраг Пипер, Ивана Антонић, Владислава Ружић, Срето Танасић, Људмила Поповић, Бранко Тошовић, Синтакса савременог српског језика: Проста реченииа, Београд: Београдска књига, Институт за српски језик САНУ; Нови Сад: Матица српска, 670-679.

Пипер/Клајн 2013: Предраг Пипер, Иван Клајн, Нормативна граматика сриског језика, Нови Сад: Матица српска.

Поповић 1997: Љубомир Поповић, Ред речи у реченищи, Београд: Друштво за српски језик и књижевност Србије.

Правопис 2010: Митар Пешикан, Јован Јерковић, Мато Пижурица, Правопис српског језика, измењено и допуњено издање, редакција измењеног и допуњеног издања Мато Пижурица, Милорад Дешић, Бранислав Остојић, Живојин Станојчић, Нови Сад: Матица српска.

Симеон 1969: Rikard Simeon, Enciklopedijski rječnik lingvističkih naziva II, Zagreb: Matica hrvatska.

Стевановић 1979: Михаило Стевановић, Савремени српскохрватски језик (граматички системи и књижевнојезичка норма) II (Синтакса), треће издање, Београд: Научна књига.

Стевановић 1981: Михаило Стевановић, Савремени српскохрватски језик (граматички системи и књижевнојезичка норма) I увод, Фонетика, Морфологија), четврто издање, Београд: Научна књига.

Стијовић 2012: Рада Стијовић, JЕЛ' ИЛИ ЈЕР, у: Језички саветник, Београд: Чигоја штампа, 139-140.

Фекете 2008: Егон Фекете, Једна правописна несугласица, у: Језичке доумиие, књига друга, Београд: Београдска књига, 70-72.

Худечек/Вукојевић 2007: Lana Hudeček, Luka Vukojević: Da li, je li i li-normativni status i raspodjela, Rasprave Instituta za hrvatski jezik i jezikoslovlje, knj. 33, Zagreb, 217-234. 
Miloš M. Kovačević

\section{ON THE TMETIC PERMUTATION OF THE “LI" ENCLITICS IN COLLOQUIAL LANGUAGE}

\section{Summary}

In the paper, on examples from the journalistic sub-style of publicistic style of the Serbian language, one specific type of non-normative conversational (colloquial) interrogative construction is analyzed from structural, semantic and normative aspects: Je l'ste zdravo?

In this construction there is a linear restructuring of the part of the predicate expressed by the copulative or auxiliary verb biti (jesam). The accented form in present of the verb biti is broken down into two parts - to je and the enclitic form: sam, si, smo, ste and su. The apocopied form of the interrogative particle $l i$ (form $l$ ') is interpolated between the "je" component and the enclitic form of present of the verb biti, so that we get the tmetic three-lexic structure: je +1'+ enclitic form in present of the verb biti (in all persons except in the third person signular): Je l'si dobro?; Je l'smo se dogovorili? etc.

Key words: colloquial language, tmesis, interrogative sentence, non-normativeness, particle "li", compound particle "da li", enclitic compound "je li". 